\title{
PENGARUH TEKNOLOGI BIG DATA TERHADAP NILAI PERUSAHAAN MELALUI KINERJA KEUANGAN PERUSAHAAN DI BURSA EFEK INDONESIA
}

\author{
Muchlis \\ muchlis-2016@feb.unair.ac.id \\ Dian Agustia \\ I Made Narsa \\ Universitas Airlangga
}

\begin{abstract}
Using the theory of Resources Based View (RBV) and the theory of Dynamic Capabilities, this study aims to examine the effect of using Big Data Technology on firm value mediated by financial performance. By using secondary data on 35 companies listed on the Indonesia Stock Exchange (IDX), using Robus regression analysis with the $R$ Studio application, this research aims to examine the relationship between increased investment in Big Data technology and Firm Value. Company value in this research is measured using TOBINSQ, Market Value Equity Ratio (MVER) and Market to Book Value Ratio (MBVR), while financial performance is measured using Return on Assets (ROA) and Return on Equity (ROE) measurements. This research also aims to compare the three measurements which significantly affect Firm Value. The findings show that there is a significant effect of increasing investment in Big Data Technology with Firm Value using the Market Value Equity Ratio (MVER) measurement and mediated by financial performance both measured using the Return on Assets (ROA) ratio and the Return on Equity (ROE) ratio.
\end{abstract}

Key words: big data, financial performance, firm value.

\begin{abstract}
ABSTRAK
Menggunakan teori Resources Based View (RBV) dan teori Dynamic Capabilities, penelitian ini bertujuan untuk menguji pengaruh penggunaan teknologi big data terhadap nilai perusahaan dengan dimediasi oleh kinerja keuangan. Dengan menggunakan data sekunder pada 35 perusahaan yang terdaftar pada Bursa Efek Indonesia (BEI), menggunakan analisis regresi robus dengan aplikasi R Studio, riset ini bertujuan untuk menguji pengaruh meningkatnya investasi teknologi big data terhadap nilai perusahaan. Nilai Perusahaan dalam riset ini diukur menggunakan TOBINSQ, Market Value Equity Ratio (MVER) dan Market to Book Value Ratio (MBVR), sedangkan kinerja keuangan diukur dengan menggunakan pengukuran Return on Assets (ROA) dan Return on Equity (ROE). Riset ini juga bertujuan untuk membandingkan ketiga pengukuran tersebut mana yang signifikan mempengaruhi nilai perusahaan. Temuan menunjukkan adanya pengaruh yang signifikan meningkatnya investasi teknologi big data dengan nilai perusahaan dengan menggunakan pengukuran Market Value Equity Ratio (MVER) dan dimediasi oleh kinerja keuangan baik diukur dengan menggunakan rasio Return on Assets (ROA) maupun dengan rasio Return on Equity (ROE).
\end{abstract}

Kata kunci: big data, kinerja keuangan, nilai perusahaan.

\section{PENDAHULUAN}

Kemajuan teknologi saat ini berkembang sangat cepat, berbagai sektor industri berlomba-lomba berinvestasi pada tools dan solusi teknologi untuk mengintegrasikan proses produksi, mesin, dan sumber daya manusianya, seluruh data tersebut dikumpulkan dan selanjutnya dianalisis untuk digunakan sebagai bahan evaluasi pada proses bisnis dan pengembangan perusaha- 
an di masa mendatang. Semua proses produksi diatur dan diawasi secara terintegrasi satu sama lain sehingga membuat proses produksi menjadi lebih fleksibel (Nagy et al., 2018). Kemajuan teknologi revolusi industri 4.0 juga dapat mengaburkan asumsi terhadap pekerjaan yang dilakukan oleh manusia dan yang dilakukan oleh mesin, oleh karena itu revolusi industri 4.0 sangat berbeda dengan revolusi industri sebelumnya, karena berdampak pada seluruh bidang kehidupan kita. Melalui kerangka kerja tersebut seluruh proses perubahan informasi dapat terjadi antara manusia dengan manusia, manusia dengan benda maupun antar benda itu sendiri (Ślusarczyk, 2018:232). Pada revolusi industri 4.0 juga ditemukan beberapa teknologi yang memungkinkan pelaku industri mengontrol proses produksinya melalui jarak jauh atau yang lebih dikenal dengan cyberphysical systems, revolusi industri 4.0 juga dipahami sebagai smart factory melalui smart digital devices yang terhubung dan berkomunikasi satu dengan lain antara mesin, peralatan, sumber daya manusia bahkan hingga robot, dimulai dari penanganan bahan baku, produk dalam proses, hingga produk selesai diproduksi (Vuksanović et al., 2016).

Revolusi industri 4.0 mulai dikenal sejak tahun 2011 di Hanover Jerman, dimana sebuah group kerja yang memberikan rekomendasi kepada pemerintah Jerman untuk mengimplementasikan teknologi cyber-physical systems, the Internet of Things (IoT), big data, cloud computing, cognitive computing, dan artificial intelligence pada dunia industri dalam menjalankan proses produksinya. Terjadinya revolusi industri 4.0 tentunya akan berdampak pada semakin berkurangnya penggunaan sumber daya manusia dalam proses produksi, dikarenakan prosesnya hampir seluruhnya telah digantikan oleh mesin dan robot yang dapat diprogram secara independen dan di-remote dari jarak jauh melalui teknologi cloud computing dan internet of things sebagaimana dikemukakan oleh Bal dan Erkan (2019), datanya kemudian diolah dengan menggunakan teknologi big data dan artificial intellingence yang akan memberikan output berupa saran perbaikan dan efisiensi proses produksi kepada manajemen. Penggunaan teknologi dalam proses produksi akan berdampak pada menurunnya tingkat biaya yang dikeluarkan selama proses produksi, namun sebaliknya akan meningkatkan kualitas dan kuantitas dari produk yang dihasilkan (Kurt, 2019). Banyak negara industri maju saat ini telah mengimplementasikan teknologi dari revolusi industri 4.0, tidak ingin tertinggal dengan negara lain di dunia, negara Indonesia juga sudah mulai mencanangkan untuk menerapkan teknologi dari revolusi industri 4.0 yaitu dengan meluncurkan roadmap arah Indonesia 4.0 yang dikeluarkan oleh Dewan Teknologi Informasi dan Komunikasi Nasional (WANTIKNAS) Republik Indonesia pada tanggal 28 oktober 2018 yang merupa-kan roadmap dalam memasuki revolusi industri 4.0 dengan mempersiapkan sumber daya manusia yang berkualitas dan kompe-ten sesuai dengan tuntutan industri (Habibie, 2018). Salah satu teknologi yang saat ini masih menjadi topik utama pemba-hasan oleh para peneliti terutama di Indonesia adalah teknologi big data. Big data adalah salah satu pendekatan yang diguna-kan untuk mengelola dan menganalisis data dengan menggunakan lima dimensi utama yaitu volume, variety, velocity, veracity, dan value (Wamba et al., 2016). Big Data juga memiliki kemampuan dalam mengolah data baik terstruktur maupun yang tidak terstruktur (Ahmed et al., 2017).

Big data adalah sebuah teknologi terbaru yang saat ini dianggap efektif untuk mengolah dan menganalisis data, baik yang terstruktur maupun tidak terstruktur, memiliki volume, variety, dan velocity sangat besar yang digunakan sebagai keunggulan bersaing bagi perusahaan (Rahman, 2017). Beberapa peneliti maupun praktisi menganggap big data adalah data yang berasal dari berbagai sumber data termasuk diantaranya adalah data sensor, satelit, 
sosial media, foto, video, dan data yang berasal dari handphone (Wamba et al., 2015). Data terstruktur berasal dari transaksi penjualan, maupun produksi, sedangkan data tidak terstruktur berasal dari media sosial seperti twitter, facebook, whatsapp, instagram, CCTV serta media sosial lainnya dapat diolah oleh teknologi ini (Kubina et al., 2015). Big data juga merupakan pengembangan dari teknologi sebelumnya yaitu business intelligence, dan berkembang seiring dengan ditemukannya teknologi Internet of Things (IoT) yang memungkinkan interaksi manusia dan mesin melalui internet. Big data juga menawarkan teknologi pemrosesan data yang belum pernah terjadi sebelumnya seperti pada teknologi Business Intelligence (BI), dan big data menyediakan analisis data yang sangat canggih (Warren et al., 2015). Data diolah dengan menggunakan teknik analisis yang disebut dengan Big Data and Predictive Analysis (BDPA) untuk dapat mengolah data yang sangat besar dan kompleks menjadi sebuah informasi yang digunakan untuk pengambilan keputusan yang lebih baik dan akurat sehingga dapat membantu organisasi untuk memahami tentang bisnis dan pasarnya (Chen et al., 2012). Beberapa riset juga menunjukkan bahwa BDPA dapat meningkatkan kinerja organisasi dan pengambilan keputusan manajemen serta mentransformasikannya ke dalam supply chain (Schoenherr dan Pero, 2015).

\section{TINJAUAN TEORETIS Teknologi Big Data}

Terdapat dua perbedaan utama dalam menganalisis data, yaitu menggunakan Big Data Analytics (BDA) dengan Business Intelligence (BI), perbedaan yang pertama adalah BI fokus pada data terstruktur yang dapat memberikan wawasan bagi manajemen dalam rangka pengambilan keputusan yang tepat. Data tersebut kemudian didefinisikan dalam bentuk query data secara luas. Berbeda dengan BI, BDA memiliki kemampuan (capabilities) yang lebih luas dalam menganalisis data, karena data yang dianalisis tidak hanya data internal yang terstruktur, namun data eksternal yang tidak terstruktur pun dalam berbagai format dan tipe data dapat diolah dan dianalisis dengan menggunakan BDA. Perbedaan yang kedua adalah pada informasi yang dihasilkan, memiliki perbedaan yang signifikan, jika BI lebih fokus pada informasi masa lalu dan apa yang telah dicapai oleh perusahaan, berbeda dengan BDA, informasi yang dihasilkan tidak hanya berfokus pada data masa lalu, namun data masa akan datang pun turut pula dianalisis dalam menentukan langkah perusahaan selanjutnya yang harus diambil. Menurut beberapa literatur tentang big data, terdapat 3 kriteria dari BDA yang disebut dengan 3V, yaitu: volume, velocity, dan variety. Volume berarti big data dapat mengolah data dengan kapasitas yang besar, velocity berarti data yang diolah memiliki frekuensi perubahan yang sangat tinggi, sedangkan variety berarti big data memiliki variasi data yang cukup banyak baik yang terstruktur maupun yang tidak terstruktur. Beberapa peneliti menyatakan bahwa BDA berpengaruh signifikan terhadap kinerja perusahaan (Akter et al., 2016). Namun dengan seiringnya waktu, big data berkembang menjadi $5 \mathrm{~V}$ dengan penambahan karakteristik dari big data yaitu veracity yang berarti bahwa big data rentan terhadap keakuratan dan validitas data, sehingga membutuhkan analisis yang mendalam agar informasi yang dihasilkan dapat mendukung pengambilan keputusan dengan tepat, dan value berarti big data akan dapat memberikan nilai yang tinggi bagi perusahaan apabila diolah dengan tepat guna (Kitchin, 2015).

Beberapa peneliti juga menyatakan bahwa BDA tidak hanya berpengaruh secara signifikan terhadap kinerja perusahaan, namun juga pada keunggulan kompetitif (competitive advantage) dari perusahaan (Charles dan Gherman, 2013); (Kubina et al., 2015); (Lukić, 2017); (Mata et al., 1995). Dari hasil riset tersebut dapat disimpulkan bahwa di era revolusi industri 4.0, informasi 
yang dihasilkan oleh teknologi big data dapat diperoleh dengan sangat cepat untuk digunakan sebagai dasar dalam pengambilan keputusan bagi manajemen perusahaan. Dalam riset ini, teknologi big data akan diukur dengan memproksikannya dengan rasio perangkat lunak. Rasio perangkat lunak diukur dengan cara membagi total investasi perangkat lunak dibagi dengan total aset perusahaan. Rasio ini digunakan untuk mengukur seberapa besar kontribusi teknologi big data dari seluruh aset yang dimiliki oleh perusahaan terhadap kinerja perusahaan.

\section{Teknologi Big Data sebagai Knowledge Management bagi Perusahaan}

Saat ini sebagian besar bisnis yang sebelumnya dikelola dan dijalankan dengan cara tradisional telah bertransformasi menjadi bisnis yang dijalankan dengan memanfaatkan teknologi informasi. Bisnis tersebut dijalankan melalui berbagai macam perangkat digital dan terhubung melalui internet dan dapat diakses dimanapun dan kapanpun. Data transaksi bisnis sudah tidak lagi dalam bentuk laporan yang dicetak di atas kertas (hardcopy) tetapi telah berubah menjadi data digital (softcopy) dengan berbagai tipe data seperti teks, angka, suara, gambar, dan video. Teknologi tersebut juga melibatkan berbagai perangkat digital seperti memory, bandwidth, processing, server, dan jaringan yang datanya disimpan dalam sebuah perangkat lunak yang disebut dengan database. Data yang terkumpulpun seluruhnya sudah berbentuk data digital, dari mulai data penjualan, pembelian, stok, produk, produksi, logistik hingga laporan keuangan, sehingga membutuhkan teknik analisis data yang jauh berbeda dengan sebelumnya (Ferraris et al., 2019). Saat ini teknik analisis data jauh lebih murah dibandingkan sebelumnya yaitu dengan memanfaatkan teknologi analisis big data. Teknologi big data memiliki kemampuan untuk mengolah data yang sangat besar, memiliki kecepatan perubahan yang sangat tinggi dengan tipe data yang sangat beragam (Rahman, 2017). Dengan kemampuan big data dalam mengelola dan memproses data yang sangat besar dengan kecepatan pemrosesan data dengan sangat cepat menjadikan penerapan knowledge management di perusahaan menjadi semakin efektif karena didukung dengan berbagai jenis data baik yang terstruktur seperti data penjualan, data produksi dan data keuangan, maupun yang tidak terstruktur seperti data dari media sosial maupun sumber data lainnya yang berasal dari eksternal perusahaan, digunakan sebagai sumber informasi untuk diolah dan diubah oleh big data menjadi informasi yang digunakan sebagai knowledge bagi perusahaan.

\section{Teknologi Big Data sebagai Keunggulan Kompetitif Perusahaan}

BDA di era disrupsi saat ini sangat dibutuhkan untuk membantu proses pengambilan keputusan bagi manajemen, terutama dalam pengambilan keputusan strategis. Beberapa riset menunjukkan adanya hubungan yang postif antara BDAC dengan kinerja perusahaan. BDAC juga dapat digunakan sebagai knowledge management (Santoro et al., 2017) yang digunakan sebagai sarana meningkatkan keunggulan kompetitif perusahaan melalui inovasi produk. Keunggulan kompetitif akan tercapai apabila perusahaan dapat mengoptimalkan kapasitas sumber dayanya, terutama dalam hal mengintegrasikan sumber daya yang ada untuk mencapai tujuan yang ditetapkan. Pengelolaan pengetahuan (knowledge management) yang baik dan dimanfaatkan dalam rangka menciptakan suatu nilai (value) dalam setiap proses produksi, produk serta pelayanan dapat pula meningkatkan keunggulan kompetitf perusahaan dibanding dengan kompetitornya (Collymore et al., 2017). Pengelolaan pengetahuan (knowledge management) dalam era disrupsi saat ini tidak lepas dari pemanfaatan sumber data yang dimiliki oleh perusahaan, baik yang terstruktur maupun yang tidak. Big data adalah sebuah teknologi 
yang dapat mengolah data dengan volume yang sangat besar, dengan perubahan data yang sangat cepat dan tipe data yang begitu banyak dapat digunakan sebagai salah satu resources yang dapat memberikan keunggulan kompetitif (competitive advantage) bagi perusahaan (Mikalef et al., 2019). Dalam riset ini, competitive advantage diukur dengan memproksikannya dengan Asset Turn Over (ATO) (Sar, 2017).

\section{Kapabilitas yang harus Dimiliki dalam Penerapan Teknologi Big Data}

Kim et al. (2012) menyatakan bahwa terdapat pendekatan dalam riset tentang teknologi informasi yang dilihat dari sudut pandang sociomaterialism, dimana menurut pandangan ini, teknologi informasi dianggap sebagai sebuah aspek integral yang tidak dapat dipisahkan dari kehidupan berorganisasi dikarenakan setiap kegiatan manusia bergantung kepada sesuatu yang bersifat material. Menurut pandangan ini juga menyatakan bahwa manusia dan teknologi memiliki peran yang sama-sama penting, tidak ada yang lebih penting dari lainnya, sehingga tercipta keseimbangan antara keduanya dan saling melengkapi. Sociomaterialism melihat kapabilitas teknologi informasi melalui 3 dimensi yaitu: kapabilitas manajemen teknologi informasi, kapabilitas infrastruktur teknologi serta kapabilitas yang berasal dari keahlian yang dimiliki oleh personil yang terlibat, sehingga perusahaan dikatakan memiliki kapabilitas dalam bidang teknologi informasi apabila memiliki keungulan dalam ketiga kriteria tersebut.

\section{Kapabilitas Manajemen Teknologi Informasi}

Kemampuan dalam manajemen sangat diperlukan terutama dalam hal melakukan perencanaan, investasi, koordinasi dan kontrol termasuk bagaimana mengendalikan dan mengelola sumber daya teknologi informasi yang dimiliki perusahaan tersebut untuk digunakan sesuai dengan kebutuhan dan skala prioritas. Menurut Kim et al.
(2012), perencanaan teknologi informasi, pengambilan keputusan investasi teknologi informasi, koordinasi teknologi informasi, dan pengendalian teknologi informasi merupakan satu pondasi yang utuh dan tidak terpisahkan sebagai sebuah kapabilitas dalam manajemen teknologi informasi.

\section{Perencanaan Teknologi Informasi}

Perencanaan teknologi informasi wajib untuk dibuat sebelum sebuah teknologi big data digunakan dan diimplementasikan di dalam perusahaan. Membuat perencanaan adalah kegiatan yang rutin dilakukan oleh bagian teknologi informasi di perusahaan agar pemanfaatan teknologi informasi dapat dilakukan dan dilaksanakan secara terstruktur dalam rangka mendukung fungsi bisnis perusahaan. Selain perencanaan perlu ditentukan juga strategi yang akan diterapkan dalam merealisasikan rencana tersebut. Setelah perencanaan dan strategi disusun selanjutnya adalah menyusun peta jalan (road map) yang bertujuan untuk menentukan bagaimana tahapan realisasi perencanaan tersebut dilakukan berdasarkan tahapan pekerjaan dan waktu pengerjaan. Beberapa tahapan penting dalam perencanaan teknologi informasi adalah: 1) melakukan identifikasi kebutuhan akan aplikasi teknologi informasi yang inovatif dan memiliki manfaat bagi perusahaan, 2) menentukan skala prioritas dari aplikasi yang akan di implementasikan terlebih dahulu, 3) merencanakan bagaimana cara mendistribusikan aplikasi tersebut dalam perusahaan, 4) Melakukan revisi terhadap sistem disesuaikan dengan kondisi lingkungan, baik internal maupun eksternal perusahaan yang selalu berubah (Kim et al., 2011). Dengan melaksanakan 4 tahapan tersebut diharapkan dapat meningkatkan kemampuan teknologi informasi (information technology capabilities) yang dimiliki perusahaan.

\section{Pengambilan Keputusan Investasi Teknologi Informasi \\ Pengambilan keputusan investasi da- lam teknologi informasi sangat penting}


dalam menentukan sumber daya yang akan dipilih dan digunakan, agar dapat menguatkan posisi strategis perusahaan. Pengambilan keputusan ini dilakukan dengan mekanisme yang terstruktur dan disesuaikan dengan model pendanaan yang akan dilakukan oleh perusahaan. Sudah cukup banyak kegagalan yang terjadi diakibatkan oleh kesalahan dalam pengambilan keputusan investasi teknologi informasi sehingga terjadi pembengkakan biaya. Penyumbang terbesar dari kegagalan tersebut adalah ketidakmampuan dalam memprediksi investasi teknologi informasi yang dibutuhkan perusahaan di masa depan. Pengambilan keputusan investasi teknologi informasi sebaiknya dilakukan dengan menggunakan analisis biayamanfaat berdasarkan berbagai indikator penilaian terutama dari sisi keuangan, teknologi, sosial, dan budaya perusahaan agar investasi yang dilakukan akan dapat mendukung strategi bisnis perusahaan. Dari sisi keuangan, dari berbagai teknologi informasi yang ada, teknologi apa yang memiliki nilai manfaat yang besar dengan biaya investasi yang lebih rendah. Dari sisi teknologi, apakah teknologi yang akan diterapkan sesuai dan kompatibel dan dapat diintegrasikan dengan sistem yang sudah ada dan digunakan saat ini oleh perusahaan. Sedangkan dari sisi sosial dan budaya, apakah teknologi yang diterapkan sesuai dengan budaya perusahaan dan dapat pula diterima diimplementasikan oleh seluruh stakeholder perusahaan.

\section{Koordinasi Teknologi Informasi}

Koordinasi antara teknologi informasi dan bisnis dilakukan dengan cara melakukan sinkronisasi lintas fungsi dengan melalui laporan, kontak fisik secara langsung, koordinasi antar gugus tugas, serta pertemuan formal dan informal antar tim di lintas departemen. Desain dari struktur organisasi dan proses bisnis yang diterapkan di perusahaan sangatlah penting dan dibutuhkan dalam hal melakukan koordinasi antar departemen sehingga tercipta saluran informasi yang formal dan bersifat horizontal antar unit dalam organisasi perusahaan. Selain itu perlu disusun aturan tentang proses koordinasi yang akan dilakukan antar fungsi dalam melakukan interaksi, menentukan jumlah frekuensi pertemuan, frekuensi waktu dalam setiap pertemuan serta apa yang akan dicapai dari proses komunikasi tersebut.

\section{Pengendalian Teknologi Informasi}

Pengendalian dilakukan agar proses penerapan teknologi informasi yang telah direncanakan sebelumnya dapat berjalan sesuai dengan yang diharapkan. Pengendalian dapat dilakukan baik secara formal maupun informal dan membutuhkan komitmen dari sumber daya, baik sumber daya manusia maupun anggaran teknologi informasi. Salah satu contoh pengendalian adalah dengan menyusun proposal biaya sesuai dengan rencana anggaran yang telah ditentukan, tanggung jawab dari unit kerja bidang teknologi informasi serta mengembangkan suatu kriteria kinerja bagi layanan teknologi informasi. Agar pengendalian dapat berjalan dengan efektif dan terstruktur juga perlu disusun tata kelola teknologi informasi agar seluruh aturan formal dan informal, peran dan tanggung jawab masingmasing bagian yang terlibat. Tata kelola juga digunakan untuk mengatur serta mengendalikan semua kegiatan yang berkaitan dengan teknologi informasi.

\section{Kapabilitas Infrastruktur Teknologi Big Data \\ Connectivity}

Konektivitas (connectivity) adalah sebuah kemampuan dari infrastruktur teknologi informasi agar dapat terhubung dengan sistem yang lain yang berbeda dengan yang digunakan saat ini, seperti sistem ERP dapat dihubungkan dengan sistem Customer Relationship Management (CRM) atau ERP dengan Supply Chain Management (SCM). Infrastruktur teknologi 
informasi yang bersifat eksklusif dan sulit untuk terkoneksi atau diintegrasikan dengan sistem lain akan menghambat perkembangan bisnis perusahaan di masa mendatang, sehingga kemampuan terkoneksi dengan sistem lain merupakan syarat mutlak dalam mengembangkan teknologi informasi. Kemampuan konektivitas yang dimiliki oleh teknologi big data tidak hanya pada perangkat lunak (software) namun pada perangkat keras (hardware) dan jaringan (networking). Kemampuan ini akan menjadikan teknologi ini menjadi sangat fleskibel dan tidak membutuhkan investasi infrastruktur yang cukup mahal karena dapat terhubung dengan infrastruktur cloud. Gambaran konektivitas teknologi big data dengan sistem lain yang berbeda seperti ditunjukkan pada gambar 1 .

\section{Compatibility}

Kompatibilitas (compatibility) adalah kemampuan dari suatu sistem dalam melakukan integrasi dengan sistem lain, contoh seperti operating systems, perangkat keras (hardware), dan perangkat lunak (softwre) baik dalam lingkungan internal maupun eksternal perusahaan. Pemilihan sistem operasi yang digunakan berhubungan dengan arsitektur dari Central
Processing Unit (CPU) apakah menggunakan Intel (WindowsOS) ataukah menggunakan power PC (MacOS). Agar teknologi informasi dapat kompatibel dengan sistem lain adalah dengan menggunakan operating systems yang sama, sebab hal ini akan memudahkan perusahaan dalam mengintegrasikan infrastrukturnya termasuk melakukan relasional databasenya. Dengan menggunakan sistem operasi yang sama, secara ekonomis juga akan meminimalkan biaya pelatihan kepada pengguna sistem, karena mereka sudah terbiasa dengan sistem yang sudah ada saat ini. Dengan sistem operasi yang sama, antar pengguna juga dapat berbagi pakai data seperti spreadsheets, word processing, file data, dan email. Agar sistem selalu uptodate dan mengikuti perkembangan, sistem harus di update secara berkala, rata-rata update sistem adalah setiap 2 hingga 3 tahun, proses ini akan mengatasi masalah adanya bug dari program lama dan masalah kompatibilitas perangkat lunak. Penggunaan hardware maupun software yang tidak compatible berakibat pada terhambatnya proses bisnis perusahaan.

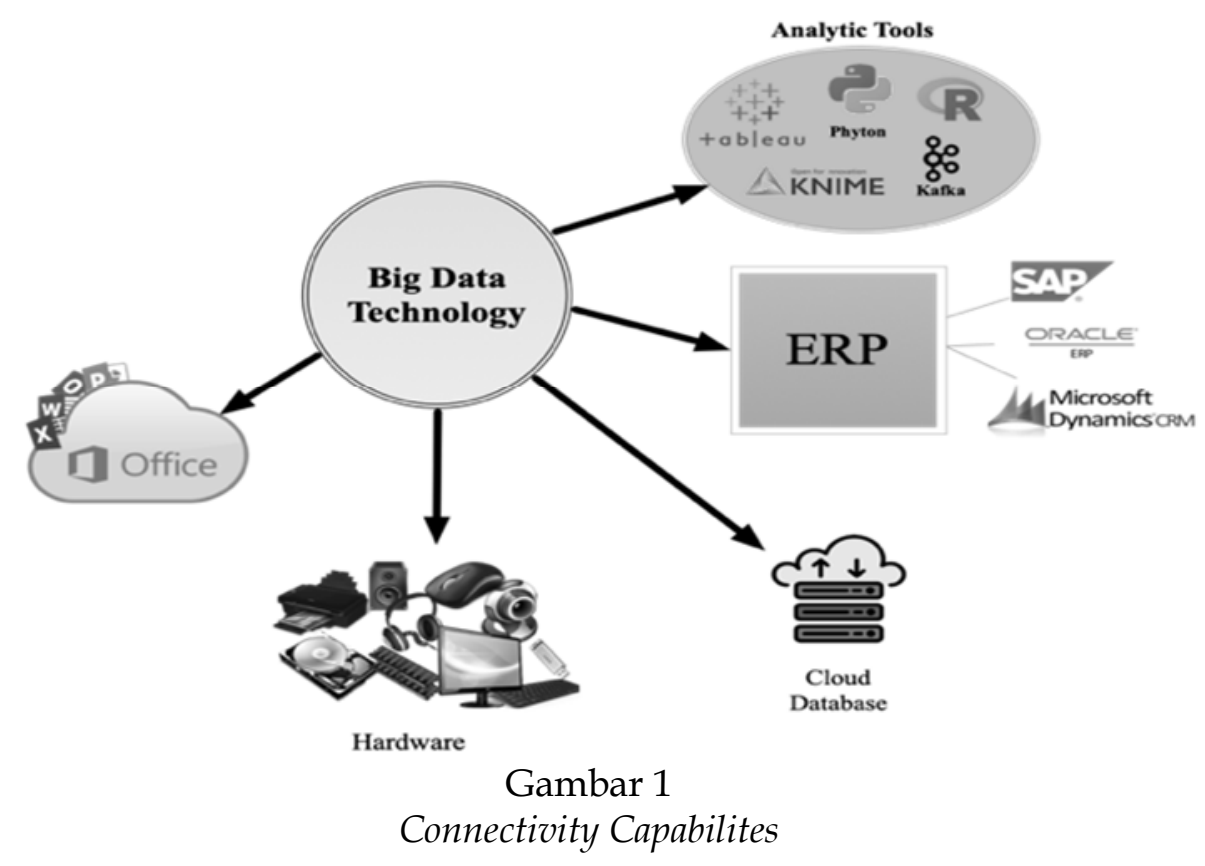




\section{Modularity}

Modularitas (modularity) adalah kemampuan dari sistem untuk ditambah, diedit, dihapus maupun dimodifikasi berdasarkan modul-modul aplikasi. Kemampuan ini sangat penting apabila terjadi perubahan prosedur maupun fungsi dari sebagian komponen dari sebuah sistem atau software tanpa harus merubah seluruh sistem yang ada, cukup modul tertentu saja yang berubah. Merubah sebuah sistem atau software tanpa merubah keseluruhan sistem akan memudahkan dalam pengembangan sistem di masa mendatang menyesuaikan kondisi lingkungan internal maupun eksternal perusahaan yang selalu berubah. Dengan adanya kemampuan ini, biaya pengembangan sistem akan menjadi lebih hemat karena apabila ada pengembangan pada modul tertentu misal modul keuangan, maka tidak perlu merubah keseluruhan sistem, cukup modul keuangan saja yang dilakukan perubahan.

\section{Kapabilitas Pengalaman Personil}

Pengalaman profesional personil seperti pengetahuan dan ketrampilan yang dimiliki sangat dibutuhkan dalam menunjang tugas yang diberikan. Staf teknologi informasi harus memiliki kompetensi sesuai dengan 4 keahlian yang berbeda dan sama pentingnya yaitu: memiliki pengetahuan dalam bidang teknis (misal: bahasa pemrograman yang dikuasai, sistem operasi, manajemen database dan jaringan), memiliki pengetahuan tentang manajemen teknologi (misal: manajemen sumber daya teknologi informasi, penerapan teknologi informasi dan operasi), memiliki pengetahuan dalam bidang bisnis (misal: memahami unit bisnis internal) serta pengetahuan dalam bidang relationalship (misal: kemampuan berkomunikasi antar personil, dan berkolaborasi dengan masing-masing fungsi bisnis). Personil yang memiliki kompetensi akan dapat menyelaraskan antara strategi teknologi informasi dengan strategi bisnis perusahaan, serta merancang dan mendesain ulang teknologi informasi dengan mengutamakan kinerja bisnis perusahaan. Mengembangkan teknologi informasi dengan mempertimbangkan konektivitas, kompatibilitas, dan modularitas dalam mengantisipasi kebutuhan teknologi informasi di masa mendatang sesuai dengan tuntutan bisnis. Demikian juga, perusahaan yang tidak memiliki keahlian teknologi informasi akan merasa lebih sulit dalam bersaing dalam memenuhi tuntutan pasar yang serba cepat. Dalam mengembangkan kemampuan yang seimbang (cakap dalam pengetahuan bisnis dan mampu membangun kolaboratif antar fungsi), membutuhkan proses yang bertahap bagi seorang profesional dalam bidang teknologi informasi, namun apabila hal ini dapat dicapai, maka hal ini akan menjadikan suatu keunggulan bagi perusahaan karena akan sulit diduplikasi oleh pesaingnya.

\section{Teknologi Big data dan Competitive Advantage}

Teori keunggulan kompetitif pertama kali dikenalkan oleh Porter (1985). Teori ini menyatakan bahwa sukses tidaknya sebuah perusahaan ditentukan oleh keunggulan kompetitif yang dimiliki. Keunggulan dapat berasal dari kapabilitas internal maupun eksternal perusahaan. Saat ini banyak industri fokus pada memanfaatkan data sebagai salah satu keunggulan kompetitif mereka, bagaimana agar keunggulan data yang dimiliki dapat memberikan nilai tambah bagi perusahaan. Teknologi pengolahan data konvensional belum mampu dalam mengelola volume data yang cukup besar dengan perubahan data yang sangat cepat dalam waktu yang singkat. Untuk itu dibutuhkan sebuah teknologi yang terbarukan yaitu teknologi big data. Salah satu keunggulan yang dimiliki oleh teknologi big data dibandingkan dengan teknologi sebelumnya yaitu teknologi Business Intelligence (BI), adalah kemampuannya dalam menganalisis data dalam populasi yang cukup besar. Jika sebelumnya dalam menganalisis data dilakukan dengan menggunakan metode sampling dan 
membutuhkan biaya yang cukup besar, namun dengan teknologi big data, seluruh populasi dapat dianalisis sehingga tidak perlu menggunakan sampel lagi dalam menganalisis data, bahkan hipotesis tidak dibutuhkan lagi, karena seluruh data dalam fenomena dapat diregresi dan dirubah sesuai dengan kebutuhan. Agar data dapat menjadi sebuah keunggulan kompetitif, data yang dimiliki harus dapat dipertanggungjawabkan kebenarannya (veracity) agar analisis yang dilakukan terhadap data tersebut dapat memberikan hasil yang bermanfaat/nilai (value) bagi perusahaan. Banyak riset yang menunjukkan hasil yang signifikan hubungan antara teknologi big data dan keunggulan kompetitif (competitive advatage) salah satunya adalah yang dilakukan oleh Charles dan Gherman (2013), yang menambahkan 3 faktor yang penting dalam teknologi big data yaitu: konteks (context), keterhubungan (connectedness), dan kompleksitas (complexity). Diharapkan dengan adanya penambahan ketiga faktor tersebut dapat menjadikan teknologi big data sebagai salah satu keunggulan kompetitif (competitive advantage) bagi perusahaan.

\section{Teknologi Big Data dan Kinerja Keuangan}

Menurut teori Resources Based View (RBV), sebuah perusahaan agar dapat mencapai keunggulan kompetitifnya dilakukan dengan cara meningkatkan kapabilitas internal yang dimiliki, salah satunya adalah dengan menggunakan teknologi big data. Teknologi big data adalah sebuah teknologi terbarukan yang memiliki karakteristik isi yang sangat besar (volume), perubahan datanya sangat cepat (velocity), dan memiliki jenis data yang banyak (variety) (Kubina et al., 2015). Dengan teknologi ini, manajemen perusahaan dapat mengolah data kemudian menganalisis hasilnya dengan cepat dan akurat baik data terstruktur maupun yang tidak terstruktur (email, whatsapp, instagram, facebook) secara real time. Menurut riset yang dilakukan oleh Suoniemi et al. (2020) menunjukkan bahwa teknologi big data dapat meningkatkan kinerja keuangan melalui peningkatan market capabilities perusahaan. Teknologi ini menyumbang sebesar 13\% dari keseluruhan strategi diferensiasi yang diterapkan oleh perusahaan. Pengaruh karakteristik dari teknologi big data seperti volume, velocity, dan variety dengan dimediasi oleh data value dan data veracity terhadap kinerja perusahaan juga pernah diteliti oleh Ghasemaghaei (2019). Hasil riset menunjukkan bahwa data variety secara positif dapat meningkatkan perolehan data value, hal ini menunjukkan bahwa teknologi big data memiliki dampak pada kinerja perusahaan melalui data variety. Riset yang dilakukan oleh Collymore et al. (2017) menunjukkan bahwa perusahaan yang menggunakan teknologi big data sebagai bagian dari operasional sehari-hari secara signifikan menunjukkan peningkatan keunggulan kompetitif dan kinerja perusahaannya dibanding dengan perusahaan yang tidak menerapkan teknologi ini. Berdasarkan riset yang dilakukan tersebut terbukti teknologi ini dapat meningkatkan efektivitas dan efisiensi dalam pengambilan keputusan manajemen, mulai dari level operasional, taktikal hingga pada level strategik (strategical level). Dengan kecepatan yang dimiliki oleh teknologi ini pengambilan keputusan dapat dilakukan dengan cepat dan tepat. Hal ini secara langsung dapat meningkatkan kinerja keuangan perusahaan.

Berdasarkan teori RBV tersebut, hipotesis yang dapat dibangun adalah sebagai berikut:

$\mathrm{H}_{1}$ : Teknologi big data berpengaruh positif terhadap meningkatnya kinerja keuangan

\section{Kinerja Keuangan dan Nilai Perusahaan}

Menurut teori sinyal (signalling theory), terdapat 2 pihak yang terlibat, satu pihak adalah pemberi sinyal (signaller), dan pihak lain adalah penerima sinyal (receiver). Signaller mengirimkan informasi ke receiver untuk mengurangi asimetri informasi 
(Brown et al., 2020). Sinyal yang diberikan dapat berupa kinerja keuangan dalam bentuk laporan keuangan perusahaan. Kinerja keuangan adalah sebuah ukuran dari pencapaian tujuan perusahaan. Kinerja keuangan dapat diartikan juga sebagai sebuah capaian prestasi yang diinginkan perusahaan pada periode tertentu. Kinerja keuangan diukur dengan menggunakan rasio tingkat pengembalian aset (Return on Assets/ROA) dan rasio tingkat pengembalian ekuitas (Return on Equiety/ROE). Kedua rasio ini digunakan untuk mengukur efektivitas perusahaan dalam menghasilkan keuntungan. Meningkatnya kinerja keuangan tentunya akan direspon positif oleh shareholder sehingga dapat secara langsung meningkatkan nilai saham perusahaan yang kemudian berpengaruh pada meningkatnya nilai perusahaan dimata investor. Berdasarkan penjelasan tersebut, maka hipotesis yang dibangun adalah sebgai berikut:

$\mathrm{H}_{2}$ : Kinerja keuangan berpengaruh positif terhadap meningkatnya nilai perusahaan (firm value)

$\mathrm{H}_{3}$ : Teknologi big data berpengaruh positif terhadap meningkatnya nilai perusahaan (firm value) melalui Kinerja keuangan

\section{Teknologi Big Data dan Nilai Perusahaan}

Tujuan utama didirikannya perusahaan selain meraih laba, hal yang tidak kalah penting adalah meningkatkan nilai perusahaan di mata stakeholder dan shareholder. Menurut teori stakeholder pimpinan harus dapat merurumuskan suatu strategi dalam proses kegiatan perusahaan, kemudian melaksanakan strategi tersebut dengan tujuan untuk memuaskan berbagai pihak yang memiliki kepentingan dalam sebuah bisnis (Freeman dan Vea, 2001). Jensen (2001) dalam artikelnya menyatakan bahwa seorang manajer harus mampu membuat keputusan dengan tetap mempertimbangkan kepentingan dari semua stakeholder, baik secara individu maupun kelompok. Keputusan diharapkan secara substansial dapat mempengaruhi atau dipengaruhi oleh kesejahteraan perusahaan. Friedman dan Miles (2002) mengganggap bahwa jika bisnis ingin sukses, maka perusahaan harus dapat memaksimalkan laba melalui cara memproduksi barang dan jasa yang dibutuhkan, menjaga hubungan bisnis dengan para suplier, memiliki karyawan yang dapat diandalkan dan berkinerja baik, yang kesemuanya dapat bekerjasama dalam waktu jangka panjang. Dengan manajemen stakeholder yang baik, perusahaan akan dapat meningkatkan secara maksimal laba bagi perusahaan. Nilai perusahaan adalah sebuah ukuran tertentu yang digunakan untuk mengukur kepercayaan dari investor terhadap perusahaan. Meningkatnya nilai perusahaan tentunya akan menyebabkan meningkatnya kesejahteraan bagi pemiliknya (stockholder). Kesejahteraan yang diperoleh tersebut direpresentasikan berupa nilai saham. Semakin tinggi harga saham maka semakin tinggi pula nilai perusahaan, yang secara langsung dapat memberikan kepuasan berupa return yang tinggi bagi para pemegang saham. Teknologi big data juga dapat digunakan untuk memonitor dan meningkatkan proses bisnis dari perusahaan. Dengan meningkatnya proses bisnis perusahaan akan berdampak pada meningkatnya kinerja perusahaan yang kemudian dapat meningkatkan nilai perusahan di mata investor (Collymore et al., 2017).

Meningkatkan nilai perusahaan dapat dilakukan dengan berbagai cara, menurut teori RBV salah satu cara adalah dengan meningkatkan kapabilitas internal perusahaan. Untuk dapat meningkatkan kapabilitas sumber daya internal, perusahaan harus memiliki kemampuan dinamis yang baik agar dapat menyesuaikan dengan perkembangan kondisi baik internal maupun eksternal perusahaan. Salah satu cara dalam meningkatkan kemampuan dinamis perusahaan adalah dengan mengadopsi perkembangan teknologi yang terbarukan. Teknologi tersebut adalah teknologi big data. 


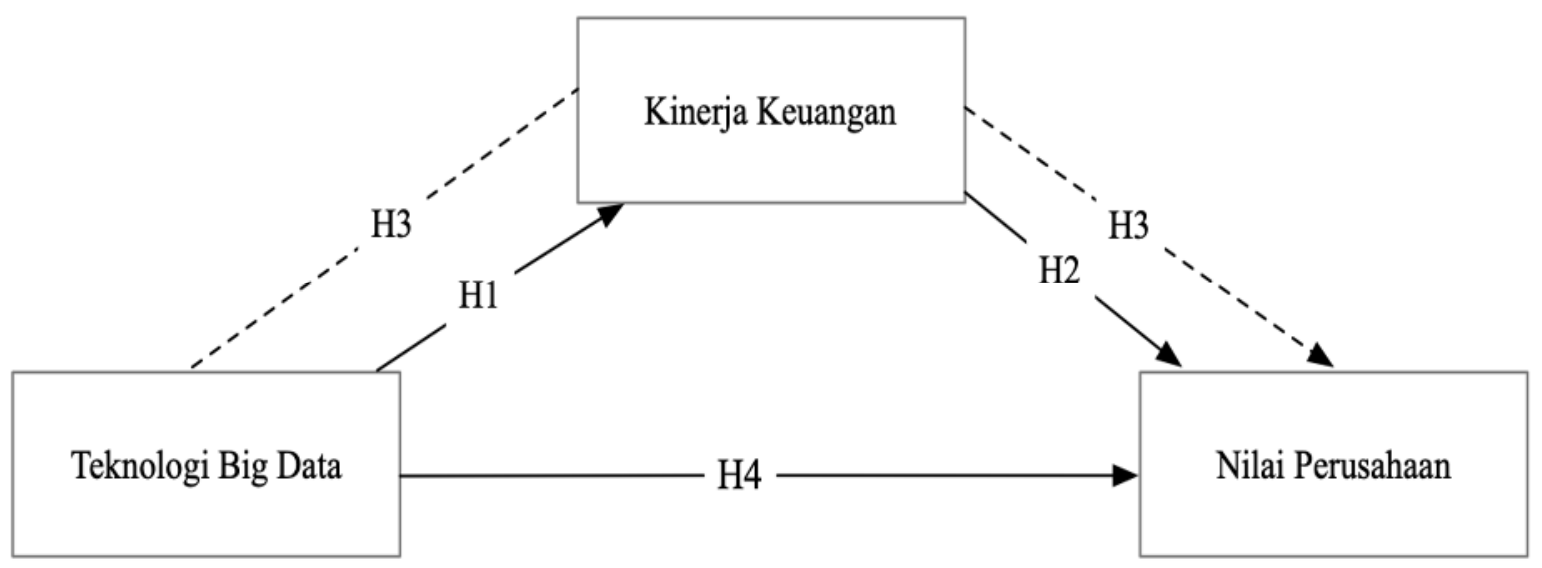

Gambar 2

Model Riset

Teknologi big data adalah teknologi terbarukan yang dapat meningkatkan kemampuan analitik perusahaan, dengan memanfaatkan data yang terstruktur maupun yang tidak terstruktur teknologi ini dapat mengolah informasi yang berasal dari kedua data tersebut untuk selanjutnya digunakan untuk memberikan informasi yang tepat dalam pengambilan keputusan manajemen. Keputusan yang tepat akan berdampak pada efektifitas dan efisiensi operasional perusahaan sehingga dapat meningkatkan kinerja keuangan perusahaan. Selain bagi manajemen, meningkatnya kualitas informasi yang dihasilkan, akan berdampak pada lancarnya komunikasi dan keterbukaan antara manajemen dan pemegang saham, sehingga tercipta transparansi di mata investor. Berdasar penjelasan di atas, hipotesis yang dibangun adalah sebagai berikut:

$\mathrm{H}_{4}$ : Teknologi big data berpengaruh positif terhadap meningkatnya nilai peruahaan (firm value)

\section{METODE PENELITIAN}

\section{Populasi dan Sampel}

Penelitian ini menggunakan metode kuantitatif dengan menggunakan data sekunder, yaitu data perusahaan go publik di pasar modal. Terdapat 35 perusahaan yang digunakan sebagai sampel dalam penelitian ini. Kesemua perusahaan adalah perusahaan yang menerapkan teknologi big data dalam kegiatan operasionalnya.

\section{Pengukuran Variabel}

Teknologi big data dalam riset ini akan diproksikan dengan rasio investasi aset tidak berwujud (intangible asset) perangkat lunak (software), rasio perangkat lunak dihitung dengan membagi investasi pada perangkat lunak dengan total aset perusahaan (perangkat lunak/total aset). Sedangkan untuk kinerja keuangan diproksikan dengan rasio tingkat pengembalian aset/ Return on Assets (ROA) yang diukur dengan cara membagi laba bersih dengan total aset (laba bersih/total aset) dan rasio tingat pengembalian ekuitas/Return on Equity (ROE) yang diukur dengan cara membagi laba bersih dengan nilai ekuitas (Penjualan/ Ekuitas) (Wijayanto, 2019). Sedangkan nilai perusahaan akan diproksikan dengan Tobins'Q, Market Value Equity Ratio (MVER) (Altman, 1968) dan Market to Book Value Ratio (MBVR) (Wijayanto, 2019). Model riset dalam penelitian ini seperti tampak pada Gambar 2.

Untuk menguji variabel mediasi digunakan metode kausal step yang dikembangkan oleh Baron dan Kenny (1986). Sedangkan tahapan dalam menggunakan metode kausal step adalah sebagai berikut: (1) Membuat persamaan regresi untuk variabel $X$ terhadap variabel $Y,(2)$ 
Membuat persamaan regresi untuk variabel $X$ terhadap variabel $M$, (3) Membuat persamaan regresi variabel $X$ terhadap variabel $Y$ dengan memasukkan variabel $M$, dan (4) Menarik kesimpulan sebagai berikut: a) Variabel $M$ dapat dikatakan sebagai mediasi yang sempurna apabila setelah memasukkan variabel $\mathrm{M}$ hubungan antara variabel $\mathrm{X}$ dan variabel $\mathrm{Y}$ yang tadinya signifikan menjadi tidak signifikan dan b) Variabel $M$ dapat dikatakan sebagai mediasi yang parsial apabila setelah memasukkan variabel $\mathrm{M}$ hubungan antara variabel $X$ dan variabel $Y$ yang tadinya signifikan menjadi tetap signifikan.

\section{Metode Analisis Data}

Data dianalisis dengan menggunakan analisis statistik regresi robus (robust regression) dengan menggunakan metode estimasi Least Trimmed Square (LTS) (Alma, 2011).

\section{ANALISIS DAN PEMBAHASAN Hasil Uji Statistik Deskriptif}

Berdasarkan hasil uji deviasi standar untuk masing-masing variabel adalah sebagai berikut: teknologi big data sebesar 0,0138, ROA sebesar 0,1343, ROE sebesar 0,3357, Tobins 'Q sebesar 9.8938, MVER sebesar 43.9575, dan MBVR sebesar 970,4866. Berdasarkan hasil statistik deskriptif seperti pada Tabel 1, diperoleh nilai mean untuk masing-masing variabel berada di bawah nilai standar deviasinya, hal ini menunjukkan bahwa variabel penelitian memiliki data yang bervariasi dan beragam.

\section{Uji Normalitas Data}

Hasil uji normalitas data dengan menggunakan metode shapiro-wilk terhadap variabel teknologi big data, kinerja keuangan, dan nilai perusahaan menunjukkan hasil nilai $p$-value $<0,05$, hasil ini menunjukkan bahwa seluruh datanya tidak berdistribusi secara normal, sehingga tidak dapat dilakukan uji dengan cara Ordinary Least Square (OLS) karena tidak terpenuhinya salah satu asumsi yaitu normalitas data. Untuk itu dibutuhkan estimasi dengan menggunakan metode lain yaitu regresi robus.

\section{Regresi Robus (Robust Regression)}

Salah satu syarat estimasi parameter dengan menggunakan metode OLS (Ordinary Least Square) adalah terpenuhinya syarat normalitas data. Berdasarkan pengujian normalitas terhadap keseluruhan variabel menunjukkan hasil $p$-value $<0,05$, sehingga dalam penelitian ini digunakan metode analisis regresi robus dengan metode estimasi LTS. Regresi robus adalah metode regresi yang digunakan ketika distribusi dari galat tidak normal atau adanya beberapa pencilan (outlier) yang berpengaruh terhadap model. Hasil uji regresi robus seperti ditunjukkan pada Tabel 2.

Tabel 1

Statistik Deskriptif

\begin{tabular}{lcrrrrr}
\hline \hline & $\boldsymbol{B D}$ & \multicolumn{1}{c}{$\boldsymbol{R O A}$} & \multicolumn{1}{c}{ ROE } & TOBINSQ & MVER & \multicolumn{1}{c}{ MBVR } \\
\hline Min & 0,0000521 & $-0,42726$ & $-0,65686$ & 0,1681 & 0,0822 & 0,215 \\
Mean & 0,0092050 & 0,09525 & 0,17974 & 3.8900 & 14.3090 & 292.329 \\
Max & 0,0651754 & 0,92100 & 0,24458 & 101.0424 & 429.7066 & 5590,000 \\
Std.Deviasi & 0,01384686 & 0,1343041 & 0,3357452 & 9.893828 & 43.95759 & 970,4866 \\
\hline
\end{tabular}

Sumber: Data sekunder yang diolah 
Tabel 2

Hasil Analisis Regresi Robus

\begin{tabular}{|c|c|c|c|c|c|c|}
\hline \multirow[t]{2}{*}{ Hipotesis } & \multirow[t]{2}{*}{ Dependen } & \multirow[t]{2}{*}{ Variabel } & \multirow[t]{2}{*}{ Koefisien } & \multirow{2}{*}{$\begin{array}{c}\text { Standard } \\
\text { error }\end{array}$} & \multirow{2}{*}{$\frac{\text { Ujit }}{p \text {-value }}$} & \multirow{2}{*}{$\frac{\text { Uji } F}{p \text {-value }}$} \\
\hline & & & & & & \\
\hline \multirow[t]{4}{*}{1} & \multirow{2}{*}{$R O A$} & Intercept & 0,051945 & 0,007861 & $0,0000^{* * *}$ & \multirow{3}{*}{0,0000} \\
\hline & & $\mathrm{BD}$ & 3.451107 & 0,467474 & $0,0000^{* * *}$ & \\
\hline & \multirow[t]{2}{*}{$R O E$} & Intercept & 0,107776 & 0,009936 & $0,0000^{* * *}$ & \\
\hline & & $\mathrm{BD}$ & 1,508286 & 0,739021 & $0,0435^{*}$ & 0,0000 \\
\hline \multirow[t]{12}{*}{2} & \multirow{2}{*}{ TOBINSQ } & Intercept & 0,2611 & 0,1839 & 0,158 & \multirow[t]{3}{*}{0,0000} \\
\hline & & ROA & 25.5664 & 1.8589 & $0,0000^{* * *}$ & \\
\hline & \multirow[t]{2}{*}{ MVER } & Intercept & 2.0277 & 0,5183 & $0,000157^{* * *}$ & \\
\hline & & ROA & 49.9925 & 3.6925 & $0,0000^{* * *}$ & \multirow[t]{2}{*}{0,0000} \\
\hline & \multirow[t]{2}{*}{$M B V R$} & Intercept & 17.478 & 5.203 & $0,00106^{* *}$ & \\
\hline & & ROA & 286.066 & 50,143 & $0,0000^{* * *}$ & \multirow{2}{*}{0,0000} \\
\hline & \multirow{2}{*}{ TOBINSQ } & Intercept & 0,5563 & 0,1148 & $0,0000^{* * *}$ & \\
\hline & & $\mathrm{ROE}$ & 11.7936 & 0,3778 & $0,0000^{* * *}$ & \multirow[t]{2}{*}{0,0000} \\
\hline & \multirow{2}{*}{ MVER } & Intercept & 3.4830 & 0,4828 & $0,0000^{* * *}$ & \\
\hline & & $\mathrm{ROE}$ & 16.5141 & 1.4349 & $0,0000^{* * *}$ & \multirow[t]{2}{*}{0,0000} \\
\hline & \multirow[t]{2}{*}{$M B V R$} & Intercept & -87.98 & 14.10 & $0,0000^{* * *}$ & \\
\hline & & $\mathrm{ROE}$ & 1171.50 & 98.87 & $0,0000^{* * *}$ & \multirow[t]{2}{*}{0,0000} \\
\hline \multirow[t]{18}{*}{3} & TOBINSQ & Intercept & 0,06651 & 0,19215 & 0,7299 & \\
\hline & & $\mathrm{BD}$ & 27.13700 & 11.74958 & $0,0228^{*}$ & \\
\hline & & ROA & 25.77187 & 2.01259 & $0,0000^{* * *}$ & 0,0000 \\
\hline & MVER & Intercept & 1.3206 & 0,4953 & 0,00883 & \\
\hline & & $\mathrm{BD}$ & 70,8756 & 31.7168 & $0,02746^{*}$ & \\
\hline & & $\mathrm{ROA}$ & 45.7217 & 4.1825 & $0,0000^{* * *}$ & 0,0000 \\
\hline & $M B V R$ & Intercept & 22.032 & 5.569 & $0,000132^{* * *}$ & \\
\hline & & $\mathrm{BD}$ & 306.260 & 389.505 & 0,433321 & \\
\hline & & ROA & 172.612 & 36.847 & $0,0000^{* * *}$ & 0,0000 \\
\hline & TOBINSQ & Intercept & 0,9213 & 0,1197 & $0,0000^{* * *}$ & \\
\hline & & $\mathrm{BD}$ & 10,8484 & 7.0956 & 0,129 & \\
\hline & & ROE & 3.5606 & 0,7898 & $0,0000^{* * *}$ & 0,0000 \\
\hline & MVER & Intercept & 3.3249 & 0,5817 & $0,0000^{* * *}$ & \\
\hline & & $\mathrm{BD}$ & 190,0360 & 42.8865 & $0,0000 * * *$ & \\
\hline & & $\mathrm{ROE}$ & 7.5793 & 2.0340 & 0,000309 & 0,0000 \\
\hline & $M B V R$ & Intercept & 18.158 & 5.811 & 0,00226 & \\
\hline & & $\mathrm{BD}$ & 217.127 & 391.540 & 0,58029 & \\
\hline & & ROE & 166.634 & 33.217 & 0,0000 & 0,0000 \\
\hline 4 & TOBINSQ & Intercept & 1.7438 & 0,1242 & $0,0000^{* * *}$ & \\
\hline & & $\mathrm{BD}$ & 17.7485 & 9.5273 & 0,0651 & 0,0000 \\
\hline & MVER & Intercept & 39.346 & 0,7134 & $0,0000^{* * *}$ & \\
\hline & & $\mathrm{BD}$ & 275.7747 & 42.7942 & $0,0000 * * *$ & 0,0000 \\
\hline & $M B V R$ & Intercept & 33.390 & 5.129 & $0,0000^{* * *}$ & \\
\hline & & $\mathrm{BD}$ & 540,690 & 400,769 & 0,18 & 0,1799 \\
\hline
\end{tabular}




\section{Uji Kelayakan Model (Goodness of Fit)}

Pada hipotesis 1, hasil perhitungan variabel ROA diperoleh nilai $p$-value sebesar 0,0000, dimana nilai $p$-value tersebut $<$ a 0,05 sehingga dapat dikatakan bahwa model layak untuk digunakan. Hasil perhitungan variabel ROE diperoleh nilai $p$-value sebesar 0,0000 , dimana nilai $p$-value tersebut $<a$ 0,05, sehingga dapat dikatakan bahwa model layak untuk digunakan.

Pada hipotesis 2 untuk ROA, hasil perhitungan variabel TOBINSQ diperoleh nilai $p$-value sebesar 0,0000 , dimana nilai $p$ value tersebut $<$ a 0,05 sehingga dapat dikatakan bahwa model layak untuk digunakan. Hasil perhitungan variabel MVER diperoleh nilai $p$-value sebesar 0,0000, dimana nilai $p$-value tersebut $<a 0,05$ sehingga dapat dikatakan bahwa model layak untuk digunakan. Hasil perhitungan variabel MBVR diperoleh nilai p-value sebesar 0,0000, dimana nilai $p$-value tersebut < a 0,05 sehingga dapat dikatakan bahwa model layak untuk digunakan. Sedangkan hipotesis 2 untuk ROE, hasil perhitungan variabel TOBINSQ diperoleh nilai $p$-value sebesar 0,0000, dimana nilai $p$-value tersebut < a 0,05 sehingga dapat dikatakan bahwa model layak untuk digunakan. Hasil perhitungan variabel MVER diperoleh nilai $p$-value sebesar 0,0000 , dimana nilai $p$-value tersebut < a 0,05 sehingga dapat dikatakan bahwa model layak untuk digunakan. Hasil perhitungan variabel MBVR diperoleh nilai $p$-value sebesar 0,0000 , dimana nilai p-value tersebut < a 0,05 sehingga dapat dikatakan bahwa model layak untuk digunakan.

Pada hipotesis 3, hasil uji F baik untuk TOBINSQ, MVER maupun MBVR menunjukkan nilai $p$-value < a 0,05 , sehingga dapat dikatakan bahwa seluruh model layak untuk digunakan.

Pada hipotesis 4, hasil perhitungan variabel TOBINSQ diperoleh nilai $p$-value sebesar 0,0000 , dimana nilai $p$-value tersebut < a 0,05 sehingga dapat dikatakan bahwa model layak untuk digunakan. Hasil perhitungan variabel MVER diperoleh nilai $p$-value sebesar 0,0000, dimana nilai $p$-value tersebut < a 0,05, sehingga dapat dikatakan bahwa model layak untuk digunakan. Hasil perhitungan variabel MBVR diperoleh nilai $p$-value sebesar 0,1799 , dimana nilai $p$-value tersebut > a 0,05 sehingga dapat dikatakan bahwa model tidak layak untuk digunakan.

\section{Hasil Uji t}

Pada Hipotesis 1, ROA: hasil perhitungan menunjukkan nilai $p$-value dari variabel $\mathrm{BD}$ adalah sebesar 0,0000, dimana nilai ini < a 0,05 , sehingga dapat dikatakan bahwa variabel $\mathrm{BD}$ berpengaruh secara signifikan terhadap variabel ROA. ROE: hasil perhitungan menunjukkan nilai $p$-value dari variabel BD adalah sebesar 0,0435, dimana nilai ini < a 0,05 , sehingga dapat dikatakan bahwa variabel BD berpengaruh secara signifikan terhadap variabel ROE.

Pada Hipotesis 2, hasil perhitungan menunjukkan nilai $p$-value ROA terhdap TOBINSQ, MVER dan MBVER masingmasing sebesar 0,0000, dimana nilai p-value $<$ a 0,05, sehingga dapt dikatakan bahwa ROA berpengaruh signifikan terhadap TOBINSQ. MVER maupun MBVR.

Pada Hipotesis 3 ROA, TOBINSQ: Hasil perhitungan menunjukkan nilai $p$ value dari variabel $\mathrm{BD}$ adalah sebesar 0,0228 , dimana nilai ini < a 0,05, sehingga dapat dikatakan bahwa BD berpengaruh signifikan terhadap TOBINSQ. Hasil perhitungan menunjukkan nilai p-value dari variabel ROA adalah sebesar 0,0000 , dimana nilai $p$-value < a 0,05, sehingga dapat dikatakan bahwa ROA berpengaruh signifikan terhadap TOBINSQ. MVER: Hasil perhitungan menunjukkan nilai $p$ value dari variabel $\mathrm{BD}$ adalah sebesar 0,02746, dimana nilai $p$-value < a 0,05, sehingga dapat dikatakan bahwa BD berpengaruh signifikan terhadap MVER. Hasil perhitungan menunjukkan nilai $p$-value dari variabel ROA adalah sebesar 0,0000, dimana nilai ini < a 0,05, sehingga dapat dikatakan bahwa ROA berpegaruh signifikan terhadap MVER. MBVR: Hasil perhitungan menunjukkan nilai $p$-value dari variabel $\mathrm{BD}$ adalah sebesar 0,433321, dimana nilai $p$ - 
value > a 0,05, sehingga dapat dikatakan bahwa BD tidak mempengaruhi secara signifikan terhadap variabel MBVR. Hasil perhitungan menunjukkan nilai $p$-value dari variabel ROA adalah sebesar 0,0000, dimana nilai ini < a 0,05, sehingga dapat dikatakan bahwa ROA mempengaruhi secara signifikan variabel MBVR.

Pada Hipotesis 3 ROE, TOBINSQ: Hasil perhitungan menunjukkan nilai $p$ value dari variabel $\mathrm{BD}$ adalah sebesar 0,129 , dimana nilai ini $>$ a 0,05 , sehingga dapat dikatakan bahwa BD tidak signifikan mempengaruhi variabel TOBINSQ. Hasil perhitungan menunjukkan nilai $p$-value dari variabel $\mathrm{ROE}$ adalah sebesar 0,0000, dimana nilai ini < a 0,05, sehingga dapat dikatakan bahwa ROE signifikan mempengaruhi variabel TOBINSQ. MVER: Hasil perhitungan menunjukkan nilai p-value dari variabel $\mathrm{BD}$ adalah sebesar 0,0000, dimana nilai ini < a 0,05 , sehingga dapat dikatakan bahwa BD mempengaruhi secara signifikan variabel MVER. Hasil perhitungan menunjukkan nilai p-value dari variabel ROE adalah sebesar 0,000309, dimana nilai ini < a 0,05, sehingga dapat dikatakan bahwa ROE mempengaruhi secara signifikan variabel MVER. MBVR: Hasil perhitungan menunjukkan nilai $p$-value dari variabel $\mathrm{BD}$ adalah sebesar 0,58029, dimana nilai ini > a 0,05, sehingga dapat dikatakan bahwa BD tidak signifikan mempengaruhi MBVR. Hasil perhitungan menunjukkan nilai $p$-value dari variabel $\mathrm{ROE}$ adalah sebesar 0,0000, dimana nilai ini < a 0,05, sehingga dapat dikatakan bahwa ROE signifikan mempengaruhi MBVR.

Pada Hipotesis 4, TOBINSQ: Hasil perhitungan menunjukkan nilai $p$-value dari variabel $\mathrm{BD}$ adalah sebesar 0,0651, dimana nilai ini > a 0,05, sehingga dapat dikatakan bahwa BD tidak signifikan mempengaruhi TOBINSQ. MVER: Hasil perhitungan menunjukkan nilai $p$-value dari variabel $\mathrm{BD}$ adalah sebesar 0,0000, dimana nilai ini $<a$ 0,05 , sehingga dapat dikatakan bahwa BD mempengaruhi secara signifikan MVER. MBVR: Hasil perhitungan menunjukkan nilai $p$-value dari variabel $\mathrm{BD}$ adalah sebesar 0,18 , dimana nilai ini > a 0,05, sehingga dapat dikatakan bahwa BD tidak signifikan mempengaruhi MBVR.

\section{Pembahasan \\ Pengaruh Teknologi Big Data terhadap Kinerja Keuangan}

Berdasarkan perhitungan uji model maupun uji hipotesis 1, menunjukkan nilai p-value $\mathrm{BD}$ terhadap ROA maupun ROE adalah sebesar 0,0000 dan 0,0435, dimana nilai keduanya baik ROA maupun $\mathrm{ROE}<\mathrm{a}$ 0,05 sehingga dapat disimpulkan bahwa teknologi big data signifikan berpengaruh terhadap kinerja keuangan, baik dengan menggunakan pengukuran Return On Assets (ROA) maupun dengan pengukuran Return on Equity (ROE). Teknologi big data adalah salah satu sumber daya yang dapat digunakan untuk meningkatkan kinerja keuangan. Dengan kemampuannya dalam melakukan analisis data menjadikan teknologi ini sebagai keunggulan kompetitif yang dapat digunakan untuk meningkatkan kinerja keuangan perusahaan (Kubina et al., 2015).

\section{Pengaruh Kinerja Keuangan terhadap Nilai Perusahaan}

ROA terhadap TOBINSQ:Hasil uji hipotesis menunjukkan nilai $p$-value 0,0000 dimana nilai $p$-value < a 0,05 sehingga dapat disimpulkan bahwa ROA signifikan mempengaruhi TOBINSQ.

ROA terhadap MVER: Hasil uji hipotesis menunjukkan nilai p-value 0,0000 dimana nilai $p$-value < a 0,05 sehingga dapat disimpulkan bahwa ROA signifikan mempengaruhi MVER.

ROA terhadap MBVR: Hasil uji hipotesis menunjukkan nilai $p$-value 0,0000 dimana nilai $p$-value $<$ a 0,05 sehingga dapat disimpulkan bahwa ROA signifikan mempengaruhi MBVR.

ROE terhadap TOBINSQ: Hasil uji hipotesis menunjukkan nilai p-value 0,0000 dimana nilai $p$-value < a 0,05 sehingga 
dapat disimpulkan bahwa ROE signifikan mempengaruhi TOBINSQ.

ROE terhadap MVER: Hasil uji hipotesis menunjukkan nilai p-value 0,0000 dimana nilai $p$-value < a 0,05 sehingga dapat disimpulkan bahwa ROE signifikan mempengaruhi MVER.

ROE terhadap MBVR: Hasil uji hipotesis menunjukkan nilai p-value 0,0000 dimana nilai $p$-value $<$ a 0,05 sehingga dapat disimpulkan bahwa ROE mempengaruhi MBVR pada tingkat signifikan $0,1 \%$.

Berdasarkan hasil uji hipotesis pengaruh kinerja keuangan terhadap nilai perusahaan dapat disimpulkan bahwa kinerja keuangan, baik diukur dengan menggunakan ROA maupun ROE signifikan berpengaruh terhadap meningkatnya nilai perusahaan. Hasil ini sesuai dengan teori stakeholder yaitu perusahaan harus memperhatikan kepentingan dari pemangku kepentingan, salah satunya adalah pemegang saham (investor) (Friedman dan Miles, 2002). Investor berkepentingan terhadap berapa nilai return yang akan mereka peroleh dari investasi yang telah mereka keluarkan. Parameter yang digunakan untuk menilai seberapa besar perusahan dapat memberikan nilai return dari investasi mereka adalah kinerja keuangan, semakin meningkat kinerja perusahaan, maka akan direspon positif oleh para investor, yang secara langsung akan meningkatkan nilai perusaahan.

\section{Pengaruh Teknologi Big data terhadap Nilai Perusahaan Dimediasi oleh Kinerja Keuangan}

TOBINSQ: Berdasarkan perhitungan uji model maupun uji hipotesis, pada persamaan 3, menunjukkan nilai $p$-value $\mathrm{BD}$ sebesar 0,0228, dan nilai p-value ROA sebesar 0,0000 baik nilai BD maupun ROA < a 0,05 sehingga dapat disimpulkan bahwa variabel ROA signifikan mempengaruhi teknologi big data terhadap nilai perusahaan, apabila menggunakan pengukuran TOBINSQ.
Market Value Equity Ratio (MVER): Berdasarkan perhitungan uji model maupun uji hipotesis, pada persamaan 3 , menunjukkan nilai p-value BD sebesar 0,02746, dan nilai $p$-value ROA sebesar 0,0000 , baik nilai $\mathrm{BD}$ maupun $\mathrm{ROA}<$ a 0,05 sehingga dapat disimpulkan bahwa variabel ROA signifikan mempengaruhi teknologi big data terhadap nilai perusahaan, apabila menggunakan pengukuran MVER.

Market to Book Value Ratio (MBVR): Berdasarkan perhitungan uji model maupun uji hipotesis, pada persamaan 3 , menunjukkan nilai p-value BD sebesar 0,433321, dimana nilai ini > a 0,05 dan nilai $p$-value $\mathrm{ROA}$ sebesar 0,0000, dimana nilai ini < a 0,05, sehingga dapat disimpulkan bahwa variabel ROA tidak signifikan mempengaruhi teknologi big data terhadap nilai perusahaan, apabila menggunakan pengukuran MBVR.

Menurut teori Resources Based View (RBV), sumber daya internal perusahaan yang dapat dikategorikan sebagai sumber daya yang memiliki keunggulan kompetitf adalah sumber daya yang memiliki kriteria Value, Rare, Immitable dan Non-substitutable (VRIN) (Barney, 1991). Teknologi big data adalah salah satu sumber daya yang memiliki kriteria tersebut, dikarenakan setiap perusahaan memiliki karakteristik dari data yang berbeda terutama data sales, distribusi, dan produksi yang melekat pada proses bisnis sehingga sangat sulit untuk diduplikasi. Dengan kemampuan dalam mengekstrak data baik data terstruktur maupun tidak terstruktur, akan meningkatkan kemampuan analisis perusahaan dalam pengambilan keputusan yang tepat. Pengambilan keputusan yang tepat dan cepat ini, akan secara langsung meningkatkan kinerja keuangan, dan selanjutnya meningkatnya kinerja keuangan akan secara langsung meningkatkan nilai perusahaan di mata investor. 


\section{Pengaruh Teknologi Big data terhadap Nilai Perusahaan}

TOBINSQ: Berdasarkan perhitungan uji hipotesis 1 , menunjukkan nilai p-value BD sebesar 0,0651, nilai ini > a 0,05 sehingga dapat disimpulkan bahwa teknologi big data tidak signifikan mempengaruhi nilai perusahaan, apabila digunakan pengukuran dengan menggunakan TOBINSQ.

Market Value Equity Ratio (MVER): Berdasarkan perhitungan uji hipotesis menunjukkan bahwa nilai p-value $\mathrm{BD}$ sebesar 0,0000, nilai ini < a 0,05 sehingga dapat disimpulkan bahwa teknologi big data signifikan berpengaruh terhadap nilai perusahaan, apabila menggunakan pengukuran Market Value Equiety Ratio (MVER).

Market to Book Value Ratio (MBVR): Berdasarkan perhitungan uji hipotesis, menunjukkan bahwa nilai p-value $\mathrm{BD}$ sebesar 0,18, nilai ini > a 0,05 sehingga dapat disimpulkan bahwa teknologi big data tidak signifikan berpengaruh terhadap nilai perusahaan, apabila menggunakan pengukuran Market to Book Value Ratio (MBVR).

Teknologi big data membantu perusahaan dalam melakukan inovasi dengan mengintegrasikan manusia (human), institusi, entitas, dan proses. Integrasi tersebut menciptakan sebuah cara yanga baru dengan memanfaatkan teknologi big data. Perusahaan dapat menggunakan data insight yang dihasilkan oleh teknologi big data dalam menunjang pengambilan keputusan terutama pada bidang keuangan (financial) dan perencanaan (planning). Dengan menggunakan teknologi big data ini pula, perusahaan dapat aktif mengikuti tren dan kebutuhan para pelanggan terhadap produk atau layanan baru. Menurut Tambe (2014), investasi pada teknologi big data dapat meningkatkan pertumbuhan produktivitas perusahaan sebesar 3\%, kenaikan produktivitas ini ditunjang oleh sumber daya manusia yang memiliki keahlian dan pengalaman dalam penguasaan aplikasi hadoop untuk pengembangan teknologi big data.

\section{SIMPULAN DAN SARAN \\ Simpulan}

Berdasarkan hasil analisis, kinerja keuangan (ROA dan ROE) dapat memediasi secara parsial (partial meiation) hubungan antara teknologi big data terhadap nilai perusahaan dengan menggunakan pengukuran Market Value Equity Ratio (MVER), baik diukur dengan menggunakan rasio Return on Assets (ROA) maupun dengan menggunakan rasio Return on Equity (ROE). Teknologi big data menjadi tidak signifikan apabila nilai perusahaan diukur dengan menggunakan pengukuran TOBINSQ dan Market to Book Value Ratio (MBVR). Dengan hasil yang diperoleh dari riset ini, menunjukkan bahwa teknologi big data sebagai sumber daya internal yang dimiliki perusahaan yang dapat meningkatkan kinerja keuangan perusahaan. (Collymore, 2017); (Wamba et al., 2016). Riset ini tetap memiliki keterbatasan diantaranya adalah data yang digunakan adalah data sekunder, data tersebut belum mencerminkan kondisi sesungguhnya dari implementasi teknologi big data yang dilakukan oleh perusahaan. Keterbatasan lainnya adalah data yang digunakan belum mencakup keseluruhan bidang usaha yang tercatat di Bursa Efek Indonesia (BEI).

\section{Saran}

Untuk riset berikutnya dalam menguji pengaruh teknologi big data dengan nilai perusahaan (firm value) dengan dimediasi dengan variabel lain selain kinerja keuangan, disarankan untuk penelitian mendatang menggunakan mixed method dengan data sekunder dan data primer dengan menggunakan pengukuran yang berbeda, agar lebih mencerminkan kondisi sesungguhnya dari implementasi dari teknologi big data dan pengaruhnya terhadap nilai perusahaan dengan menggunakan data pada perusahaan yang terdapat pada Bursa Efek Indonesia (BEI).

\section{DAFTAR PUSTAKA}

Ahmed, E., I. Yaqoob, I. A. T. Hashem, I. Khan, A. M. I. A. Ahmed, M. Imran, 
dan A. V. Vasilakos. 2017. The Role of Big Data Analytics in Internet of Things. Computer Networks 129(2017): 459-471. doi:10.1016/j.comnet.2017. 06.013.

Akter, S., S. F. Wamba, A. Gunasekaran, R. Dubey, dan S. J. Childe. 2016. How to Improve Firm Performance using Big Data Analytics Capability and Business Strategy Alignment? International Journal Production Economics 182: 113-131. doi:https://doi. org/10.1016/j.ijpe.2016.08.018.

Alma, Ö. G. 2011. Comparison of Robust Regression Methods in Linear Regression. International Journal Contemp. Math. Sciences 6(9): 409-421. doi: https://www.researchgate.net/publ ication/284946872.

Altman, E. I. 1968. Financial Ratios, Discriminant Analysis And The Prediction Of Corporate Bankruptcy. The Journal of Finance 23(4): 589-609. doi: https://doi.org/10.1111/j.15406261.1968.tb00843.x.

Bal, H. Ç. dan C. Erkan. 2019. Industry 4.0 and Competitiveness. Elsevier Procedia Computer Science 158: 625-631.

Baron, R. M. dan D. A. Kenny. 1986. The Moderator-Mediator Variable Distinction in Social Psychological Research: Conceptual, Strategic, and Statistical Considerations. Journal of Personality and Social Psychology 51: 1173-1182. doi:10.1037//00223514.51.6.1173.

Barney, J. 1991. Firm Resources and Sustained Competitive Advantage. Journal of Management 17(1): 99-120. doi:https:// doi.org/10.1177\%2F0149 20639101700108.

Brown, L. W., I. Goll, A. A. Rasheed, dan W. S. Crawford. 2020. Nonmarket Responses to Regulation: A Signaling Theory Approach. Group and Organization Management 45: 865-891. doi:10.1177/1059601120963693.

Charles, V. dan T. Gherman. 2013. Achieving Competitive Advantage Thro- ugh Big Data. Strategic Implications. Middle-East Journal of Scientific Research 16: 1069-1074. doi:10.5829/ idosi.mejsr.2013.16.08.11811.

Chen, H., R. H. L. Chiang, dan V. C. Storey. 2012. Business Intelligence And Analytics: From Big Data To Big Impact. MIS Quarterly 36: 11651188. doi:https://doi.org/10.2307/ 41703503.

Collymore, M. A., R. Muñoz, dan A. O. Castro. 2017. Big Data Analyitics, Competitive Advantage And Firm Performance. International Journal of Information Research and Review (IJIRR) 04(02): 3599-3603.

Ferraris, A., A. Mazzoleni, A. Devalle, dan J. Couturier. 2019. Big Data Analytics Capabilities and Knowledge Management: Impact on Firm Performance. Management Decision 57(8): 1923-1936. doi:DOI 10.1108/MD-072018-0825.

Freeman, R. E. dan J. M. Vea. 2001. A Stakeholder Approach to Strategic Management. Working Paper No. 0102 University of Virginia. doi:https:/ / dx.doi.org/10.2139/ssrn.263511.

Friedman A. I. dan S. Miles. 2002. Developing Stakeholder Theory. Journal of Management Studies 39: 1-21. doi:https:/ / doi.org/10.1111/14676486.00280 .

Ghasemaghaei, M. 2019. Understanding the Impact of Big Data on Firm Performance: The Necessity of Conceptually Differentiating among Big Data Characteristics. International Journal of Information Management 57: 102055. doi:https:// doi.org/10.1016 /j.ijinfomgt.2019.102055.

Habibie, I. A. 2018. Arah Indonesia 4.0. Wantiknas. Jakarta.

Jensen, M. C. 2001. Value Maximization, Stakeholder Theory, and the Corporate Objective Function. Journal of Applied Corporate Finance 14(3): 8-21. doi:https:/ /dx.doi.org/10.2139/ssrn .220671. 
Kim, G., B. Shin, dan K. K. Kim. 2011. IT Capabilities, Process-Oriented Dynamic Capabilities, and Firm Financial Performance. Journal of the Association for Information Systems 12(7): 487-517. doi:10.17705/1jais.00270.

Kim, G., B. Shin, dan O. Kwon. 2012. Investigating the Value of Sociomaterialism in Conceptualizing IT Capability of a Firm. Journal of Management Information Systems 29: 327362. doi:http://dx.doi.org/10.2753 /MIS0742-1222290310.

Kitchin. 2015. The Opportunities, Challenges and Risks of Big Data for Official Statistics. Statistical Journal of the IAOS 31(3): 471-481. doi:10.3233/ SJI-150906.

Kubina, M., M. Varmusa, dan I. Kubinova. 2015. Use of Big Data for Competitive Advantage of Company. Procedia Economics and Finance 26: 561-565. doi:10.1016/S2212-5671(15) 00955-7.

Kurt, R. 2019. Industry 4.0 in Terms of Industrial Relations and Its Impacts on Labour Life. Elsevier Procedia Computer Science 158: 590-601. doi: https://doi.org/10.1016/j.procs.201 9.09.093.

Lukić, J. 2017. The Impact of Big Data Technologies on Competitive Advantage of Companies. Facta Universitatis 14: 254-264.

Mata, F. J., W. L. Fuerst, dan J. B. Barney. 1995. Information Technology and Sustained Competitive Advantage: A Resource-Based Analysis. MIS Quarterly 19(4): 487-505.

Mikalef, P., J. Krogstie, I. O. Pappas, dan P. Pavlau. 2019. Exploring the Relationship between Big Data Analytics Capability and Competitive Performance: The Mediating Roles of Dynamic and Operational Capabilities. Information and Management 57(2): 103169. doi:https://doi.org/ 10.1016/j.im.2019.05.004.
Nagy, J., J. Olah, E. Erdei, D. Mate, dan J. Poppy. 2018. The Role and Impact of Industry 4.0 and the Internet of Things on the Business Strategy of the Value Chain-The Case of Hungary. Sustainability 10(10): 1-25. doi:10.3390/su10103491.

Porter, M. E. 1985. Competitive Advantage, Creating and Sustaining Superior Performance. The Free Press. New York.

Rahman, N. 2017. Big Data Analytics for a Sustained Competitive Advantage. Paper Presented at the Student Research Symposium. Student Research Symposium retrieved from http:// pdxscholar.library.pdx.edu/student symposium/2017/Presentations/1.

Santoro, G., D. Vrontis, A. Thrassou, dan L. Dezi. 2017. The Internet of Things: Building a Knowledge Management System for Open Innovation and Knowledge Management Capacity. Technological Forecasting $\mathcal{E}$ Social Change 136: 347-354. doi:http:// dx.doi.org/10.1016/j.techfore.2017.0 2.034 .

Sar, A. K. 2017. Competitive Advantage and Performance: an Analysis of Indian Downstream Oil and Gas Industry Academy of Accounting and Financial Studies Journal 21: 1-7.

Schoenherr., T. dan C. S. Pero. 2015. Data Science, Predictive Analytics, and Big Data in Supply Chain Management: Current State and Future Potential. Journal of Business Logistics 36(1): 120-132. doi:https:// doi.org /10.1111/jbl.12082.

Ślusarczyk, B. 2018. Industry 4.0 - Are We Ready? Polish Journal of Management Studies 171: 232-248.

Suoniemi, S., L. M. Waarden, A. Munzel, dan A. R. Zablah. 2020. Big Data and Firm Performance: The Roles of Market-Directed Capabilities and Business Strategy. Information and Management 57(7): 103365. doi: https:// doi.org/10.1016/j.im.2020.1 03365. 
Tambe, P. 2014. Big Data Investment, Skills, and Firm Value. Forthcoming, Management Science 60(6): 1452-1469. doi: https://dx.doi.org/10.2139/ssrn.229 4077.

Vuksanović, D., J. Ugarak, dan D. Korčok. 2016. Industry 4.0: the Future Concepts and New Visions of Factory of the Future Development. Paper presented at the International Scientific Conference on Information Technology and Data Related Research, Singidunum University in Belgrade: 293-298.

Wamba, S., A. Gunasekaran, S. Akter, S. J. Ren, R. Dubey, dan S. J. Childe. 2016. Big Data Analytics and Firm Performance: Effects of Dynamic Capabilities. Journal of Business Research 70: 356-365. doi:http:// dx.doi. org/10.1016/j.jbusres.2016.08.009.
Wamba, S., S. Akter, A. Edwards, dan G. Chopin. 2015. How 'Big Data' can Make Big Impact: Findings from a Systematic Review and Alongitudinal Case Study. International Journal Production Economics 165: 234246. doi:http://dx.doi.org/10.1016/ j.ijpe.2014.12.031.

Warren, J. D., K. C. Moffitt, dan P. Byrnes. 2015. How Big Data Will Change Accounting. Accounting Horizons 29: 397-407. doi:10.2308/acch-51069.

Wijayanto, A. 2019. The Effect Of Competitive Advantage on Financial Performance and Firm Value: Evidence From Indonesian Manufacturing Companies. Russian Journal of Agricultural and Socio-Economic Sciences 85(1). doi:10.18551/rjoas. 2019-01.04. 